Pobrane z czasopisma Annales H - Oeconomia http://oeconomia.annales.umcs.pl Data: 26/04/2023 14:36:03

DOI:10.17951/h.2017.51.2.245

A N N A L E S
UNIVERSITATIS MARIAE CURIE-SKLODOWSKA
LUBLIN - POLONIA
VOL.LI, 2
SECTIOH H

Nicolas Copernicus University in Toruń, Faculty of Economic Sciences and Management, Department of Organizational Behaviors and Marketing

\title{
DAWID SZOSTEK
}

dawidsz@umk.pl

\section{The Use of Marketing Research in Internal Marketing. The Methods of Measurement of Counterproductive Work Behaviours in an Organization}

\footnotetext{
Zastosowanie badań marketingowych w marketingu wewnętrznym.

Metody pomiaru kontrproduktywnych zachowań pracowników w organizacji
}

Key words: marketing research; internal marketing; Counterproductive Work Behaviours (CWB)

Slowa kluczowe: badania marketingowe; marketing wewnętrzny; zachowania kontrproduktywne

JEL codes: M31; M12

\section{Introduction}

One of the main paradigms of marketing is based upon a conviction that a starting point for any activities of an organization should include reconnaissance and understanding of customers' demands and expectations [Kaczmarczyk 2007, p. 13]. Strictly speaking, there is no marketing without marketing research. One cannot either claim that an organization is managed with the use of marketing, if it does not realise the type of research understood as "regular planning, gathering, analysing and reporting of data and conclusions relating to a specific marketing situation, in which an organization is" [Kotler 2005, p. 129].

In practice, enterprises may still remember about the paradigm in relation to a market and external customer, however, they often forget about the same in relation to internal market (employees). However, it is marketing research among the 
staff that constitutes a starting point for implementation of a concept of internal marketing.

The author aims at describing opportunities of use of marketing research in relation to an external market of an organization and, in particular, the context of identification and measurement of the scale of occurrence of counterproductive work behaviours in an organization. Specificity of the type of behaviours and their multidimensional character requires a specific research approach in internal marketing.

\section{Internal marketing vs. external marketing}

Employees undoubtedly constitute a key factor in the process of shaping of competitive advantages of an organization. Thus, the management of an organization has to undertake actions, which are "friendly" towards employees and an employee should be treated as an internal customer and be as significant as an external customer [Lancy and Ho Kit Ieng 2015, p. 4; Kaur and Sharma 2015, p. 237]. In the subject literature they have paid attention to this fact since the 70 s of the $20^{\text {th }}$ century [see: Berry et al. 1976]. Moreover, they have observed that in order to satisfy demands of an external customer properly, one should first take care of an internal customer [Munteanu et al. 2014, p. 9]. More specifically, the success of external marketing depends on the success of internal marketing [Kaur and Sharma 2015, p. 237].

This type of approach has become a paradigm for all entities striving for business excellence. It is represented as part of the concept of internal marketing, which means the use of "traditional" ("commercial") marketing, its tools and activities (including 4P) in relation to current employees of an organization as well as treatment of work itself as a product [Munteanu et al. 2014, p. 10; Kaur and Sharma 2015, pp. 237-238]. Rafiq and Ahmed [2000, p. 454] define internal marketing as "a planned effort using a marketing-like approach to overcome organizational resistance to change and to align, motivate and inter-functionally co-ordinate and integrate employees towards the effective implementation of corporate and functional strategies in order to deliver customer satisfaction through a process of creating motivated and customer-orientated employees".

Implementation of internal marketing in activities of an organization may result in a series of advantages such as, for example, improvement of the quality of employees' activities, gaining of independence by employees, increase of responsibility of the staff as well as predictability of their actions, increase of employees' commitment and satisfaction as well as the degree of their identification with the employer and increase of employees' tendency to show positive behaviours at their place of work (Organizational Citizenship Behaviour - OCB), keeping the best employees or improvement of communication within an organization [Lancy and Ho Kit Ieng 2015, pp. 5-6]. 
Implementation of internal marketing is not a matter of a few minor changes, but the need to reformulate thinking of an organization for the purposes of simultaneous focusing of activities on customers and employees [Munteanu et al. 2014, p. 10].

In the process of effective implementation of internal marketing (compare: Figure 1), a fundamental role is played by a strategic analysis of a situation, i.e. nothing more than marketing research (in this case - focusing on an internal market). The research enables an appropriate diagnosis of demands and expectations of employees as well as a situation, in which they are (often affected by specific problems).

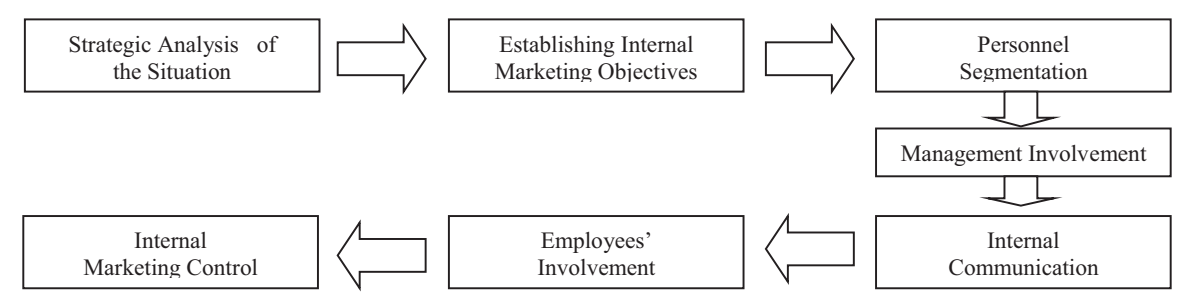

Figure 1. Internal marketing implementation

Source: Munteanu et al. [2014, p. 11].

\section{Marketing research in internal marketing}

In practice, marketing research focusing on internal customers assume forms of surveys, focus groups or individual interviews, internal online discussion groups or personality tests [Munteanu et al. 2014, p. 12]. Selection of a measurement method depends, to a great extent, on the object of measurement, which, in practice, most often includes employees' motivation and satisfaction, their opinions, attitudes, demands and expectations or tendency to adopt OCB and Counterproductive Work Behaviour (CWB).

Marketing research in internal market fulfils a lot of functions resulting in potential advantages for the organization and its stakeholders, like: informative, diagnostic, prognostic, optimising, evaluating, controlling, motivating, therapeutic, social, participating, communicative [for details see: Szostek 2011, pp. 144-145].

Whether and how many of the functions mentioned will be realised depends, to a great extent, on the organization itself and, in particular, on solutions adopted within methodology of research. One should, above all, consider such issues as [Szostek 2011, pp. 155-175]:

- an entity conducting the research - it may be an organization itself or an external research company. The smaller scope of participation of an organization itself, the greater feeling of anonymity and greater reliability,

- quantity of the group covered by the research - all employees should be measured. This will not raise any concerns connected with selection of a sample. 
In this case, functions of the research may be realised (including: therapeutic, participating and communicative functions),

- the method of data measurement - depends on many factors. It is possible to measure with the use of quantitative methods (e.g. a random, Internet or direct survey) or qualitative methods (e.g. Focus Group Interviews - FGI, individual interviews). An optimum solution involves use of triangulation of them,

- the type and structure of a measuring instrument - is determined by a measurement method. Among numerous principles in building a measuring instrument [cf. Kaczmarczyk 2003, pp. 100-111], a sensitive element are demographic questions (the greater they are, the lower is the feeling of anonymity),

- anonymity of respondents/data confidentiality - anonymity means that a measuring person is not able to match answers received with a respondent. In case of data confidentiality, a researcher is able to match the same, but he does not disclose the results to other persons. Anonymity is most desired, as its growth leads to the growth of the feeling of safety among respondents, which increases reliability of the measurement. If no anonymity can be guaranteed, data confidentiality should be ensured [McConnell 2003, p. 30],

- informative activities at the stage of preparation and realization of the research and upon completion of the same - it is important to inform employees, at particular stages of marketing research (e.g. purposes and reasons for the research, advantages for employees and an organization, an entity conducting the research, organizational issues, anonymity/confidentiality, source of additional information). It is equally important to notify employees of results of the research as well as activities undertaken in response to the same,

- use of the research results - if the main purpose of the research is to support managerial decisions and activities [Walters 1996, p. 95], it should be properly communicated to the employees, to whom the decisions and activities relate directly or indirectly. In this way, the staff will feel that they have a real influence on functioning of the organization. What is more, subsequent marketing research in internal market will also be approved.

\section{Counterproductive work behaviours and their measurement}

The organization will not be able to achieve its aims without its staff undertaking optimum activities [Nerdinger 2011, p. 410]. Thus, monitoring, explaining, forecasting and managing of behaviours of employees is a manifestation of implementation of internal marketing.

An organization should focus not only on productive behaviours (serving achievement of its aims), but also on counterproductive behaviours, i.e. those, which, when assumed deliberately, infringe aims of the organization and are detrimental to the 
organization itself as well as to its stakeholders [Nerdinger 2011, p. 416]. In the subject literature, the behaviours are often referred to as dysfunctional, deviating, pathological, retaliating or detrimental [Anjum and Parvez 2013, p. 418]. One may indicate a lot of manifestations of such behaviours, starting from less detrimental activities (such as being late for work, leaving work too early, impoliteness) and ending with grave actions (also legally sanctioned) such as verbal or non-verbal violence, sexual harassment, mobbing/bullying, sabotage or thefts in the place of work [Pecker and Fine, 2015, p. 89]. The authors indicate numerous reasons for counterproductive behaviours, including, most frequently, the feeling of injustice at work, employees' attitudes and personality features, inability to exercise self-control [Nerdinger 2011, p. 419].

In the subject literature (among others, due to ambiguity in understanding of the phenomenon, its causes and manifestations), there is no agreement as to the definition of counterproductive behaviours. There are also a lot of classifications of the behaviours. For example, Gruys and Sackett [2003] have indicated 87 manifestations of counterproductive behaviours, which they have divided into 7 separate categories. However, one of the most famous classifications in the literature as created in relation to deviant behaviours, is a typology suggested by Robinson and Bennett [1995, p. 565].

Spector et al. [2006, pp. 448-450] suggested the most coherent classification of counterproductive behaviours and divided the same into the following five categories: 1) abuse against others (causing physical or mental harm to colleagues); 2) production deviance (omission or infringement of one's duties); 3) sabotage (destroying of corporate property); 4) theft (misappropriation of corporate property or property of other employees); 5) withdrawal (limitation of worktime below the level necessary for appropriate achievement of aims of an organization).

The measurement of manifestations, scale and causes of counterproductive behaviours is a very complicated issue [Pecker and Fine 2015, p. 89]. However, it is necessary for proper management of the same.

Most frequent methods of measurement of counterproductive behaviours include [Pecker and Fine 2015, p. 90]:

- monitoring of safety and principles of works (e.g. CCTV, timesheets) - unfortunately, the methods do not allow for measurement of numerous manifestations of CWB and, in some cases, such behaviours may be identified after a long time or numerous trials,

- "hot-lines" - employees may report any cases of discriminating behaviours or those, which infringe principles of ethics or safety anonymously on the indicated telephone number or by e-mail/in writing,

- survey methods among the current employees - most frequently realized with the use of survey methods using specialist scales for measurement of counterproductive behaviours. In case of measurements made among the current employees, a weak point is lower reliability of the measurement re- 
sults resulting from the fear of (even anonymous) admitting to showing such behaviours,

- exit surveys or exit interviews - conducted among the former employees shortly after their leaving an organization and most often also with the use of specialist scales. A strong point is that the former employees are more honest (which results in greater reliability of the measurement) as compared to the current employees.

The above-mentioned scale of measurement of counterproductive behaviours may relate to employees' attitudes towards involvement in such behaviours or frequency of their involvement in specific manifestations of CWB. In the other case, the data obtained are more reliable, as they allow for establishment of an actual scale of occurrence of the behaviours in an organization [Spector et al. 2010, p. 781].

Specialist scales may include one or a few selected forms of CWB. In the first case, one should indicate at least Interpersonal Conflict Scale At Work (ICAWS) used for measurement of possible conflicts within an organization. In practice of measurement of different manifestations of counterproductive behaviours, most often used and most reliable is Counterproductive Work Behaviour Checklist (CWB-C) ${ }^{1}$. It has been developed by Spector et al. [2006] and it has 3 variations depending on the number of items in the scale $(10,32,45)$, which relate to each of the 5 categories in the above-mentioned typology of counterproductive behaviours suggested by Spector and co-authors. Each of the formulations has organizational (O) or interpersonal (I) dimensions. A respondent is asked to refer to each of them by selecting answers in the scale from 1 to 5, where: (1) Never, (2) Once or twice, (3) Once or twice per month, (4) Once or twice per week, (5) Every Day. Examples of the formulations include: "Taken a longer break than you were allowed to take" $(\mathrm{O})$, "Insulted someone about their job performance" (I), "Destroyed property belonging to someone at work" (I).

\section{Conclusions}

To sum up the deliberations presented in this article, it should be stated that the author has succeeded in achievement of his aim. In the first part of this article, the author has defined internal marketing and described its specificity as compared to external marketing. Further, attention has been focused on marketing research on internal market of an organization, including, functions of the research and most significant methodological issues connected with the same. The final part of the text is devoted to the issue of counterproductive behaviours and measurement of the same as wall as presentation of assumptions of measurements scales most frequently used in practice. The author hopes that this article will allow for achievement of additional aims such as paying attention to relevance and complexity of the issue of

\footnotetext{
1 More information about CWB-C: http://shell.cas.usf.edu/ pspector/scales/cwbcpage.html
} 
CWB as well as consequences of such types of behaviours for an organization. This article also contributes to further empirical research in the field of use of marketing research in measurements of CWB.

\section{Bibliography}

Anjum, M.A., Parvez, A., Counterproductive Behavior at Work: A Comparison of Blue Collar and White Collar Workers, "Pakistan Journal of Commerce and Social Sciences”, vol. 7, no. 3, 2013, pp. 417-434.

Berry, L.L., Hensel, J.S., Burke, M.C., Improving Retailer Capability for Effective Consumerism Response, "Journal of Retailing" vol. 52, no. 3, 1976, pp. 3-14.

Gruys, M.L., Sackett, P.R., Investigating the Dimensionality of Counterproductive Work Behavior, "International Journal of Selection and Assessment", vol. 11, no. 1, 2003, pp. 30-42.

Kaczmarczyk, S., Badania marketingowe. Metody i techniki, PWE, Warszawa 2003.

Kaczmarczyk, S., Zastosowania badań marketingowych. Zarzadzanie marketingowe i otoczenie przedsiębiorstwa, PWE, Warszawa 2007.

Kaur, J., Sharma, S.K., Internal Marketing: Scale Development and Validation, "The Journal of Business Perspective", vol. 19, no. 3, 2015.

Kotler, Ph., Marketing, Rebis Sp. z o.o., Poznań 2005.

Lancy, M., Ho Kit Ieng, S., The Impact of Internal Marketing on Organizational Commitment: The Mediating Roles of Customer Orientation and Internal Communication, "Euro Asia Journal of Management", vol. 25, no. 1-2, 2015, pp. 3-13.

McConnell, J.H., How to Design, Implement, and Interpret an Employee Survey, American Management Association, New York 2003.

Munteanu, C.C., Pagalea, A., Cristea, A., A Holistic Approach on Internal Marketing Implementation, "Business Management Dynamics", vol. 3, no. 11, 2014, pp. 09-17.

Nerdinger, F.W., Formen des Arbeitsverhaltens, Springer, Berlin-Heidelberg 2011.

Pecker, G., Fine, S., Using Exit Surveys to Assess Counterproductive Work Behaviors: A Case Study, "Psychological Reports: Employment Psychology \& Marketing”, vol. 116, no. 1, 2015, pp. 89-96.

Rafiq, M., Ahmed, P.K., Advances in the Internal Marketing Concept: Definition, Synthesis and Extension, "Journal of Service Marketing", vol. 14, no. 6, 2000, pp. 449-462.

Robinson, S., Bennett, R., A Typology of Deviant Workplace Behaviors: A Multidimensional Scaling Study, “Academy of Management Journal”, vol. 38, no. 2, 1995, pp. 555-572.

Spector, P.E., Fox, S., Penney, L.M., Bruursema, K., Goh, A., Kessler, S., The Dimensionality of Counterproductivity: Are All Counterproductive Behaviors Created Equal?, "Journal of Vocational Behavior", vol. 68, no. 3, 2006, pp. 446-460.

Spector, P.E., Bauer, J.A., Fox S., Measurement Artifacts in the Assessment of Counterproductive Work Behavior and Organizational Citizenship Behavior: Do We Know What We Think We Know?, "Journal of Applied Psychology", vol. 95, no. 4, 2010, pp. 781-790.

Szostek, D., Wykorzystywanie wyników badań opinii pracowników w kształtowaniu wewnętrznego wizerunku przedsiębiorstw województwa kujawsko-pomorskiego (unpublished doctoral thesis, defended at the Faculty of Economic Sciences and Management of the Nicolaus Copernicus University in Torun on 11.07.2011).

Walters, M., Employee Attitude and Opinion Surveys, Chartered Institute of Personnel and Development, UK 1996. 


\section{The Use of Marketing Research in Internal Marketing.} The Methods of Measurement of Counterproductive Work Behaviours in the Organization

The article describes the use of marketing research in relation to the internal market of an organization, particularly in the context of identifying and measuring the prevalence of Counterproductive Work Behaviours (CWB), e.g. mobbing, theft or destruction of company's property, verbal and non-verbal violence against employees. The article consists of three main parts: 1. Internal marketing vs. external marketing, 2. Marketing research in internal marketing and 3. CWB and measurement of the same.

\section{Zastosowanie badań marketingowych w marketingu wewnętrznym.}

\section{Metody pomiaru kontrproduktywnych zachowań pracowników w organizacji}

W artykule opisano kwestię wykorzystywania badań marketingowych w odniesieniu do wewnętrznego rynku organizacji, szczególnie w kontekście identyfikacji oraz pomiaru skali występowania zachowań kontrproduktywnych (np. mobbing, kradzieże czy niszczenie własności firmowej, przemoc werbalna i niewerbalna wobec współpracowników). Artykuł składa się z trzech zasadniczych części: 1. Marketing wewnętrzny a marketing zewnętrzny, 2. Badania marketingowe w marketingu wewnętrznym oraz 3 . Zachowania kontrproduktywne i ich pomiar. 